\title{
Determinants of geographical distribution in Atlantic Forest species of Drymophila (Aves: Thamnophilidae)
}

\author{
Henrique Rajão'; Rui Cerqueira' \& Maria Lucia Lorini²
}

\begin{abstract}
${ }^{1}$ Laboratório de Vertebrados, Departamento de Ecologia, IInstituto de Biologia, Universidade Federal do Rio de Janeiro, Caixa Postal 68020, 21941-590 Rio de Janeiro, Rio de Janeiro, Brasil. E-mail: henrique.rajao@gmail.com

${ }^{2}$ Laboratório de Gestão da Biodiversidade, Departamentto de Botânica, Programa de Pós-Graduação em Ecologia, IInstituto de Biologia, Universidade Federal do Rio de Janeiro. Caixa Postal 68029, 21941-971 Rio de Janeiro, Rio de Janeiro, Brasil. E-mail: marialucia.lorini@gmail.com
\end{abstract}

\begin{abstract}
Climate, altitude and vegetation are usually considered as limiting factors in plant and animal distribution. Among vertebrates, climate and vegetation have consistently been considered as major determinants of geographical distributions. Here we analyzed the role of climate and the vegetation in limiting the geographical range of Atlantic Forest species of Drymophila Swainson, 1824 and assessed the performance of discriminant analysis to model the distribution of sympatric taxa. From each empirical point (locality) we recorded the values for nine climatic variables and the type of vegetation. The climatic data were obtained from a climate database elaborated by the Laboratório de Vertebrados and vegetation data from the ecoregions digital map of Latin America. The overlap of the climatic distribution map with the ecoregion map suggested that both factors are important in limiting the geographical range of Drymophila species. The discriminant approach, as applied here, was not satisfactory when compared with similar analysis carried out on parapatric species.
\end{abstract}

KEY WORDS. Biogeography; climate; potential distribution; sympatric species; vegetation.

The distribution of a species is influenced by a wide range of factors, encompassing abiotic processes, biologically mediated processes, and processes dominated by biotic interactions (MACKey \& Lindenmayer 2001). Many of these determining factors operate at different spatial and temporal scales, imposing limits on species distribution that can be manifested from local up to global spatial scales. Therefore, in the realized geographic space, there are areas where the organisms may exist and areas where they do not (CERQUeIra 1995). These distributional limits are generally determined by environmental abiotic factors (e.g. temperature, humidity), biotic interactions (e.g. competitors, predators), and dispersal capacities of the organisms (Terborgh 1971, Macarthur 1972, Whittaker et al. 1973 , Terborgh \& Weske 1975, Guisan \& Thuiller 2005, Soberón \& Peterson 2005). Understanding this ensemble of factors is fundamental in order to gain insight on species geographical distribution at any spatial scale (CERQueIra 1995).

Furthermore, the limits of geographical distribution and the abundance within the boundaries of a species' range are extremely dynamic, and seem to be correlated to changes in the limiting factors (Brown \& Lomolino 1998, NewTon 2003). Consequently, ascertaining the factors that shape the distribution of a species can be more important than determining the boundaries of its geographical range (GRELLE \& CERQUeIRA 2006). Knowing these determinants enables the design of predictive modeling experiments like forecasting future scenarios.

Climate, altitude and vegetation are usually considered limiting factors in the distribution of plants and animals. Among vertebrates, climate and vegetation have been consistently considered as major determinants of geographical distribution (Walker 1990, Lindenmayer et al. 1991, Carrascal et al. 1993, Law 1994, Boggs \& Murphy 1997, Pastor-Nieto \& Willianson 1998, Cueto \& Casenave 1999, Jackson \& Claridge 1999, CATLing et al. 2000). Climate, in particular, acts directly upon physiological processes, and indirectly by determining changes in resource availability (NewTon 2003). On a broad geographical scale, the effects of climate may be more important than habitat structure. By contrast, on a local scale, we expect the opposite to be true (Myers \& GILler 1988).

Central to the predictive modeling approach is the concept of potential distribution. This concept implies that, for each empirical geographical distribution point (locality) there are corresponding values of limiting factors (predictor variables). An evaluation of these variables makes it possible to establish the limits of the potential geographical distribution (Cerqueira 1985, 1995, Cerqueira et al. 1998, Austin 2007). An implicit premise of this approach is that each species occupies a specific adaptive zone characterized by a singular ensemble of environmental characteristics (VAN VALEN 1976). The potential geographical distribution of a species corresponds to an 
area that has suitable conditions for its occurrence at a given time. In this area, not all localities are expected to be occupied concurrently. (TAYlor \& TAYlor 1979, Cerqueira 1995).

Most methods used to determine potential distributions compare data from empirical points of known occurrence against data from localities where the species is supposedly absent. This procedure has several drawbacks since absence is hypothetical, whereas presence is empirical (Fielding \& BeLL 1997). One way to overcome such limitation is to compare data from the known occurrence of a target species with data from the localities of occurrence of phylogenetically related species. Considering that species occupy adaptive zones that are minimally distinct from one another, the comparison among data from true occurrence localities of different species can reveal the factors that contribute to shape the distribution of each. Such an approach can be particularly promising to modeling the potential distribution of allopatric and parapatric taxa (Vilanova et al. 2005, Grelle \& Cerqueira 2006). However, the performance of this method in modeling the distribution of sympatric taxa remains to be assessed. To fill this gap, the present study addresses the use of discriminant analyses in modeling the potential distribution of Brazilian Atlantic Forest antbirds of Drymophila Swainson, 1824, a group that encompasses sympatric and syntopic species.

Drymophila includes eight species: six are endemic to the Atlantic Forest - D. squamata (Lichtenstein, 1823), D. ferruginea (Temminck, 1822), D. rubricollis (Bertoni, 1901), D. genei (Filippi, 1847), D. ochropyga (Hellmayr, 1906), D. malura (Temminck, 1825) -, one lives in the Amazon region - D. devillei (Menegaux \& Hellmayr, 1906) -, and one inhabits the Andes - D. caudata (Sclater, 1855) (Ridgely \& Tudor 1994, Zimmer \& Isler 2003).

The geographic distribution of Drymophila in the Atlantic Forest extends from the state of Alagoas (Northern Brazil) to the State of Rio Grande do Sul (Southern Brazil) and two neighboring countries, Paraguay and Argentina. Drymophila occurs from sea level to an elevation of 2,000 m, and the included species are geographically superimposed (WILLIs 1988, Ridgely \& Tudor 1994, Sick 1997, Leme 2001, Zimmer \& Isler 2003, RAJão \& CERQUEIRA 2006). In a study on the elevational distribution and sympatry of Drymophila species in the Atlantic Forest, Rajão \& CERQUeIra (2006) demonstrated that, for most part, only one or two species occur in each locality, although up to six species have been registered in a few places. Their analysis also revealed that co-occurrence of species is restricted to narrow elevation bands, suggesting a low to moderate degree of sympatry and syntopy. Among vertebrates of the Brazilian Atlantic Forest, sympatry is not common, and Drymophila represents a remarkable example

In a phylogenetic analysis based on mitochondrial DNA, J. Goerck (unpublished data) found close relationships between three pairs of sister-species: (1) D. ferruginea and D. rubricollis; (2) D. genei and D. ochropyga; (3) D. caudata and D. devillei (Zimmer \& Isler 2003). All species of Drymophila in the Atlantic
Forest are monotypic, with one exception, D. squamata. Some authors recognize two putative subspecies for this taxon, $D$. $s$. squamata, occurring in the states of Alagoas and Bahia, and $D$. s. stictocorypha, from southeastern Brazil (Pinto 1978, Zimmer \& IsLER 2003)

The objectives of this study were: (1) to analyze the correlation between occurrence localities of the species of Drymophila from the brazilian Atlantic Forest with climatic and vegetation predictor variables, (2) to model the potential distributions of these species, (3) to establish the factors determining the geographical distribution of these Atlantic Forest antbirds, and (4) to assess the performance of discrimant analysis to model the distribution of sympatric taxa.

\section{MATERIAL AND METHODS}

We compiled data on the occurrence localities of Drymophila spp. mostly from specimens deposited in Brazilian museum, including the following collections: Museu de Biologia Mello Leitão (ES), Museu de História Natural Capão da Imbuia (PR), Museu Nacional do Rio de Janeiro (RJ), Museu de Zoologia of the Universidade de São Paulo (SP) and the ornithological collection of the Departamento de Zoologia of the Universidade Federal de Minas Gerais (MG). Data from the literature and bona fide unpublished records were also included. Geographical coordinates and altitudes from occurrence localities were obtained from the following sources: UnITED STATES BoARD ON GEOGRAPHICAL Names (1963), Paynter \& Traylor (1991) and Vanzolini (1992).

Additional records from North American collections and related geographical coordinates were kindly provided by $\mathrm{P}$. Cordeiro (see CoRDEIRo 2001). Data recorded by P. Cordeiro were from the following collections: American Museum of Natural History (New York), National Museum of Natural History (Washington), Academy of Natural Sciences of Philadelphia (Philadelphia), Field Museum of Natural History (Chicago), Museum of Zoology of Louisiana State University (Baton Rouge).

We recorded a total of 198 collecting localities for the six Drymophila species endemic to the Atlantic Forest: D. ferruginea (88); D. rubricollis (40); D. genei (9); D. ochropyga (48); D. malura (60); D. squamata (87). Several localities have more than one species recorded.

The climatic factors associated with a species make up the species' climatic envelope (Hijmans \& Graham 2006). In order to establish such an envelope we recorded the following climatic variables from each empirical point (locality): mean annual temperature, mean annual minimum temperature, mean annual maximum temperature, absolute minimum temperature, absolute maximum temperature, total mean annual rainfall, mean annual nebulosity, mean annual relative humidity and mean annual raining days. We chose the variables listed above because of their perceived biological relevance, and the spatiotemporal availability of data, obtained from a climate database elaborated by the LABVERT (Laboratório de Vertebrados, Universidade Federal do Rio de Janeiro). Data from 
localities with no meteorological stations were interpolated from the climate database, according to a methodology also developed by the LABVERT. This methodology has been used to study potential distribution of organisms (see Vilanova et al. 2005, Grelle \& Cerqueira 2006).

Vegetation data for each empirical point were obtained from the "ecoregions digital map" (Dinerstein et al. 1995, Olson et al. 2001) (Fig. 1). The ecoregions have similar limits to the plant formations shown in a brazilian official vegetation map (IbGe 1993), called "Mapa de Vegetação do Brasil", produced by IBGE (Instituto Brasileiro de Geografia e Estatística).

To estimate the potential distribution of the Drymophila species we followed the discriminative heuristic approach proposed by Cerqueira and colaborators (CERqUeIra 1995, CERQUEIRA et al. 1998). Following their method, we tested the normality of the climatic variables through a Kolmogorov-Smirnov test and transformed all values to their natural logarithms. In order to test for differences in climate requirements between species, we used two statistical tests: one way ANOVA and a Scheffé multiple range test, and a canonical discriminant analysis using all climate variables. When climate differences were detected, we proceeded as described below. A methodological necessity when trying to ascertain the potential distribution of a target species is to identify the climate variables that are correlated with its distribution (CERQUeIra et al. 1998). When climate differences were detected, we proceeded to identify which variables are important in the distribution of each species of Drymophila. To accomplish this goal, we used two analyses, following the procedures adopted by CerqueIra (1995): (1) an analysis of variance for each variable, contrasting the data as- sociated with each species against the combined data for all other species; (2) a canonical discriminant analysis treating each species as a group and the set composed by the remaining species as another group. The variables selected by the analysis of variance (those significantly different at the $5 \%$ level) and by the canonical discriminant analysis (those most strongly correlated with the function) were used to draw climate envelop maps for each species. We performed all analyses using the SYSTAT version 7.0 package (Spss 1997).

Using the program Surfer 8.0 (GOLDEN 2002), we drew potential distribution maps for each species by taking isopleths of mimimum and maximum values for the climate variables previously selected by the statistical analysis. In a GIS we produced a vegetation map for each species (vegetation envelope) by clipping the ecoregions map in order to retain only the ecoregions with occurrence records. Then we used intersection operation to overlay the climate envelope and vegetation envelope maps for each species. The resultant layer delimiting the intersection area of these two maps represents the potential distribution. This final map is a spatially explicit hypothesis about the species geographical distribution. The clipping, overlay and the final layout of the maps were conducted using the program ArcView GIS version 3.2 (EsRI 2000).

\section{RESULTS}

\section{Potential distribuitions and their determinants}

Table I shows the number of localities and frequencies of occurrence of each species of Drymophila by ecoregion. Drymophila species occur in six ecoregions: Serra do Mar Coastal Forests (Florestas Costeiras da Serra do Mar), Bahia Coastal For-

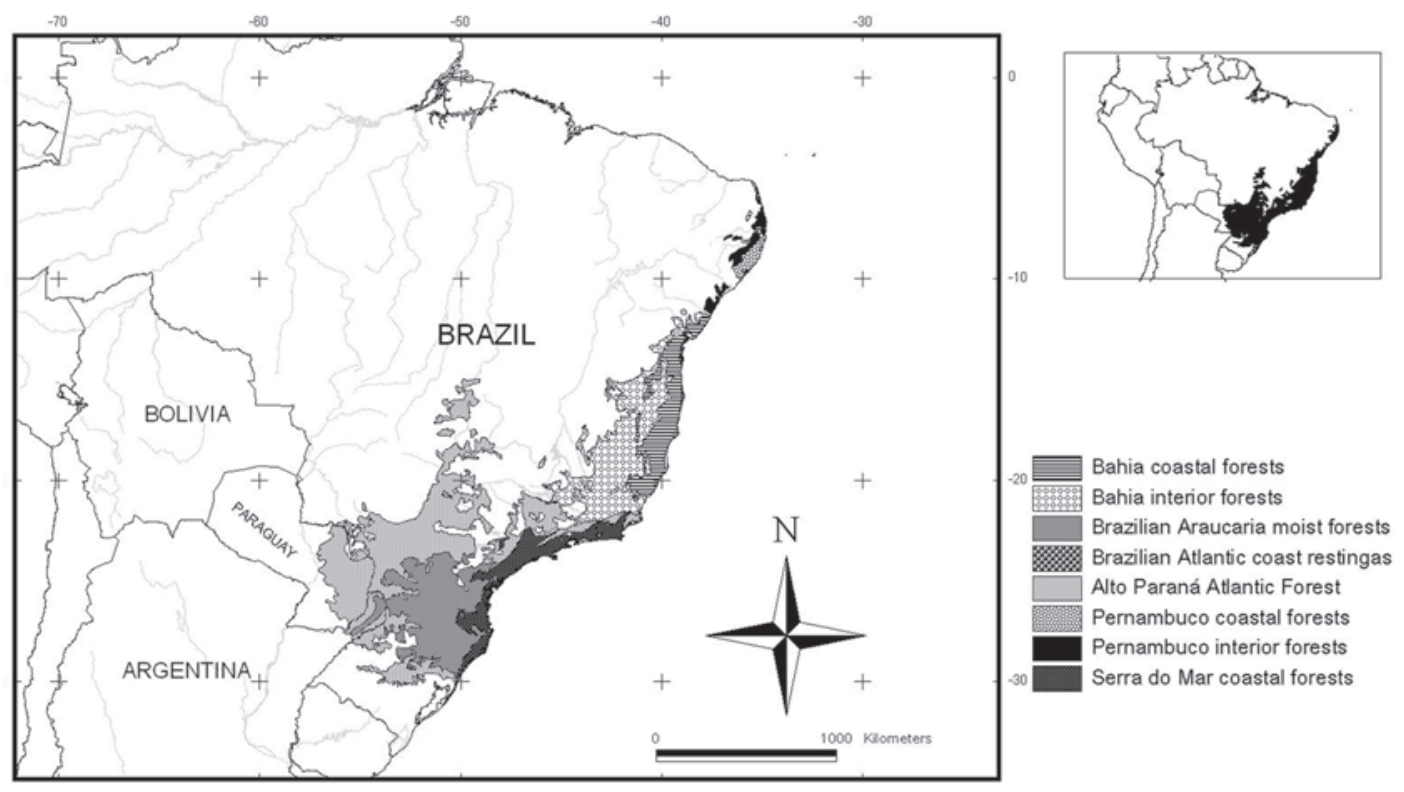

Figure 1. Atlantic Forest ecoregions (DINERSTEIN et al. 1995, OLson et al. 2001). 
ests (Florestas Costeiras da Bahia), Bahia Interior Forests (Florestas de Interior da Bahia), Araucaria Moist Forests (Florestas de Araucária), Alto Paraná Atlantic Forest (Florestas do Alto Paraná) and Pernambuco Coastal Forests (Florestas Costeiras de Pernambuco).

Only two ecoregions in the Atlantic Forest do not have occurrence localities of Drymophila spp.: Pernambuco Interior Forests (Florestas de Interior de Pernambuco) and Atlantic Coast Restingas (Restingas da Costa Atlântica). Only the range of $D$. squamata encompasses all six ecoregions and reaches the Pernambuco Coastal Forests further north. Three ecoregions have records for all species: Serra do Mar Coastal Forests, Alto Paraná Atlantic Forest and Bahia Interior Forests.

The sister-species D. ferruginea and D. rubricollis thrive in the same five ecoregions (all but Pernambuco Coastal Forests). Drymophila malura also occurs in five ecoregions, excepting the Bahia Coastal Forests. The ranges of the other pair of sisterspecies, D. genei and D. ochropyga, include the least number of ecoregions: three and four, respectively. Both species occur in the Serra do Mar Coastal Forests, Bahia Interior Forests and Alto Paraná Atlantic Forest ecoregions. Drymophila ochropyga also occurs in the Bahia Coastal Forests.

A simple analysis highlighting the two most important ecoregions per species, selected from a rank ordered by their frequency numbers, revealed the following associations: $D$. squamata in the Serra do Mar Coastal Forests and Bahia Coastal Forests; D. ferruginea, D. rubricollis and D. malura in the Serra do Mar Coastal Forests and Alto Paraná Atlantic Forest; D. genei and D. ochropyga in the Serra do Mar Coastal Forests and Bahia Interior Forests (Tab. I).

\section{Climate envelope}

The results from the one way analysis of variance and the Scheffé multiple range test are shown in table II. Eight out of nine variables were significantly different at the 5\% level. Scheffé test results indicated that, with two exceptions, all variables (absolute maximum temperature and annual total precipitation) presented significant differences between at least two species. Linear discriminant analysis showed that $38.84 \%$

Table I. Number of localities and frequencies (in parentheses) of Drymophila in Atlantic Forest ecoregions.

\begin{tabular}{|c|c|c|c|c|c|c|}
\hline Ecoregion & D. squamata & D. ferruginea & D. rubricollis & D. genei & D. ochropyga & D. malura \\
\hline Serra do Mar Coastal Forests & $31(36 \%)$ & $40(45 \%)$ & $10(25 \%)$ & $6(67 \%)$ & $21(44 \%)$ & $16(27 \%)$ \\
\hline Bahia Coastal Forests & $41(47 \%)$ & $14(16 \%)$ & $2(5 \%)$ & 0 & $5(10 \%)$ & 0 \\
\hline Pernambuco Coastal Forests & $1(2 \%)$ & 0 & 0 & 0 & 0 & 0 \\
\hline Bahia Interior Forests & $9(10 \%)$ & $9(10 \%)$ & $7(17 \%)$ & $2(22 \%)$ & $15(31 \%)$ & $5(9 \%)$ \\
\hline Alto Paraná Atlantic Forest & $3(3 \%)$ & $23(26 \%)$ & $15(38 \%)$ & $1(11 \%)$ & $7(15 \%)$ & $23(39 \%)$ \\
\hline Araucaria Moist Forests & $2(2 \%)$ & $3(3 \%)$ & $6(15 \%)$ & 0 & 0 & $15(25 \%)$ \\
\hline Total & 87 & 89 & 40 & 9 & 48 & 59 \\
\hline
\end{tabular}

Table II. Results of one way analysis of variance on climate data and the Scheffé multiple range test. For each variable are presented the $F$ value, the associated probability $(p)$ and the species which average values were significantly different. (Meantemp) mean annual temperature, (Mintemp) mean annual minimum temperature, (Maxtemp) mean annual maximum temperature; (Abmin) absolute minimum temperature, (Abmax) absolute maximum temperature, (Prec) annual total precipitation, (Neb) mean annual nebulosity, (RH) mean annual relative humidity, (RD) mean annual rainy days, (DF) Drymophila ferruginea, (Dr) D. rubricollis, (Dg) D. genei, (Do) D. ochropyga, (Dm) D. malura, (Ds) D. squamata, $\left({ }^{*}\right)$ no significative difference between means $(\mathrm{p} \leqslant 0.05)$.

\begin{tabular}{|c|c|c|c|c|c|c|c|c|}
\hline Variable & $\mathrm{F}$ & $\mathrm{p}$ & Df & $\mathrm{Dr}$ & $\mathrm{Dg}$ & Do & $\mathrm{Dm}$ & Ds \\
\hline Meantemp & 25.70 & $<0.0001$ & $\mathrm{Dr} / \mathrm{Dm} / \mathrm{Ds}$ & $\mathrm{Df} / \mathrm{Ds}$ & Ds & $\mathrm{Dm} / \mathrm{Ds}$ & Df/Do/Ds & $\mathrm{Df} / \mathrm{Dr} / \mathrm{Dg} / \mathrm{Do} / \mathrm{Dm}$ \\
\hline Mintemp & 27.48 & $<0.0001$ & $\mathrm{Dr} / \mathrm{Dm} / \mathrm{Ds}$ & Df/Ds & Ds & $\mathrm{Dm} / \mathrm{Ds}$ & Df/Do/Ds & $\mathrm{Df} / \mathrm{Dr} / \mathrm{Dg} / \mathrm{Do} / \mathrm{Dm}$ \\
\hline Maxtemp & 9.95 & $<0.0001$ & $\mathrm{Dm}$ & Ds & * & * & DF/Ds & $\mathrm{Dr} / \mathrm{Dm}$ \\
\hline Abmin & 23.39 & $<0.0001$ & $\mathrm{Dr} / \mathrm{Dm}$ & Df/Do/Ds & * & $\mathrm{Dr} / \mathrm{Dm}$ & Df/Do/Ds & $\mathrm{Dr} / \mathrm{Dm}$ \\
\hline Abmax & 1.05 & 0.3869 & * & * & * & * & * & * \\
\hline Prec & 3.87 & 0.0020 & * & * & * & * & * & * \\
\hline Neb & 4.23 & 0.0010 & * & Ds & * & * & * & $\mathrm{Dr}$ \\
\hline $\mathrm{RH}$ & 5.03 & 0.0002 & Ds & * & * & * & * & Df \\
\hline $\mathrm{RD}$ & 4.94 & 0.0002 & Ds & Ds & * & * & Ds & $\mathrm{Df} / \mathrm{Dr} / \mathrm{Dm}$ \\
\hline
\end{tabular}


of the localities are correctly classified. The first two canonical functions accounted for $87.26 \%$ of the variance $(\lambda$ de Wilks $\leqslant 0.0009$ ). In this first step, despite the low performance presented by the discriminant analysis, the analysis of variance pointed to a general differentiation in climate conditions of the target species

Once climate differences were found, we developed a means to identify which variables were appropriate to determinate the climate envelope of each species. The results of the one way analysis of variance of two groupings, comparing each species with the remaining five species, are shown in table III. The climate variables for which significant differences were found between a given species and the remaining group are indicated.
The linear discriminant analysis results demonstrated that $74.5 \%$ of the cases are correctly classified for D. malura (Wilks's $\lambda$ with $\mathrm{p}<0.0001) ; 70.1 \%$ of the cases are correctly classified for D. squamata (Wilks's $\lambda$ with $\mathrm{p}<0.0001$ ); $66.7 \%$ for $D$. genei (Wilks's $\lambda$ with $\mathrm{p}=0.0172$ ); $66.7 \%$ for $D$. ochropyga (Wilks's $\lambda$ with $\mathrm{p}=0.5772$ ); $63.6 \%$ for $D$. ferruginea (Wilks's $\lambda$ with $\mathrm{p}=$ 0.0134 ); and $42.5 \%$ for $D$. rubricollis (Wilks's $\lambda$ with $\mathrm{p}<0.0001$ ). Results of the correlation between discriminant variables and the first canonical function are shown in table IV, where the most correlated variables are also indicated.

Climatic variables selected by the variance and discriminant analysis were used to estimate the climate envelope of each Drymophila species and plot the area delineated by its cli-

Table III. Results of one way analysis of variance on climate data. Each species was tested against the other five combined. For each variable are presented the $F$ value and associated probability $(p)$. (Meantemp) mean annual temperature, (Mintemp) mean annual minimum temperature, (Maxtemp) mean annual maximum temperature; (Abmin) absolute minimum temperature, (Abmax) absolute maximum temperature, (Prec) annual total precipitation, (Neb) mean annual nebulosity, (RH) mean annual relative humidity, (RD) mean annual rainy days. $\left(^{*}\right) p \leqslant 0.05$.

\begin{tabular}{|c|c|c|c|c|c|c|c|c|c|c|c|c|}
\hline \multirow{2}{*}{ Variable } & \multicolumn{2}{|c|}{ D. squamata } & \multicolumn{2}{|c|}{ D. ferruginea } & \multicolumn{2}{|c|}{ D. rubricollis } & \multicolumn{2}{|c|}{ D. genei } & \multicolumn{2}{|c|}{ D. ochropyga } & \multicolumn{2}{|c|}{ D. malura } \\
\hline & $\mathrm{F}$ & $p$ & $\mathrm{~F}$ & $\mathrm{p}$ & $\mathrm{F}$ & $p$ & $\mathrm{~F}$ & $p$ & $\mathrm{~F}$ & $\mathrm{P}$ & $\mathrm{F}$ & $p$ \\
\hline Meantemp & 76.41 & $0.0000^{*}$ & 1.76 & 0.1851 & 10.82 & $0.0011^{*}$ & 5.60 & $0.0185^{*}$ & 0.92 & 0.3370 & 41.91 & $0.0000^{*}$ \\
\hline Mintemp & 77.27 & $0.0000^{*}$ & 2.79 & 0.0958 & 22.63 & $0.0000^{*}$ & 4.00 & $0.0461^{*}$ & 0.63 & 0.4285 & 5.50 & $0.0000^{*}$ \\
\hline Maxtemp & 20.96 & $0.0000^{*}$ & 3.47 & 0.0634 & 3.10 & 0.0791 & 0.10 & 0.7572 & 0.21 & 0.6476 & 31.20 & $0.0000^{*}$ \\
\hline Abmin & 47.91 & $0.0000^{*}$ & 3.35 & 0.0683 & 41.01 & $0.0000^{*}$ & 0.27 & 0.6064 & 0.62 & 0.4333 & 27.33 & $0.0000^{*}$ \\
\hline Abmax & 1.58 & 0.2102 & 2.91 & 0.0888 & 1.11 & 0.2929 & 0.18 & 0.6686 & 0.80 & 0.3717 & 0.18 & 0.6719 \\
\hline Prec & 4.14 & $0.0428^{*}$ & 2.72 & 0.0999 & 5.51 & $0.0195^{*}$ & 1.53 & 0.2170 & 1.13 & 0.2893 & 7.80 & $0.0055^{*}$ \\
\hline Neb & 14.62 & $0.0002^{*}$ & 0.73 & 0.3921 & 9.50 & $0.0022^{*}$ & 0.11 & 0.7460 & 0.06 & 0.8137 & 1.23 & 0.2683 \\
\hline $\mathrm{RH}$ & 18.40 & $0.0000^{*}$ & 13.54 & $0.0003^{*}$ & 0.01 & 0.9226 & 0.60 & 0.4383 & 0.03 & 0.8640 & 0.84 & 0.3590 \\
\hline $\mathrm{RD}$ & 22.48 & $0.0000^{*}$ & 1.16 & 0.2830 & 6.06 & $0.0144^{*}$ & 0.05 & 0.8285 & 0.51 & 0.4754 & 1.54 & 0.2156 \\
\hline
\end{tabular}

Table IV. Results of the correlation between discriminant variables and the first canonical function comparing each one species with the remaining five species The variables most correlated with the function are indicated by the asterisk. (Meantemp) mean annual temperature, (Mintemp) mean annual minimum temperature, (Maxtemp) mean annual maximum temperature; (Abmin) absolute minimum temperature, (Abmax) absolute maximum temperature, (Prec) annual total precipitation, (Neb) mean annual nebulosity, (RH) mean annual relative humidity, (RD) mean annual rainy days.

\begin{tabular}{lcccccc}
\hline \multicolumn{1}{c}{ Variable } & D. squamata & D. ferruginea & D. rubricollis & D. genei & D. ochropyga & D. malura \\
\hline Meantemp & $0.8016^{*}$ & 0.2843 & $0.4532^{*}$ & $-0.5159^{*}$ & 0.3448 & $0.9193^{*}$ \\
Mintemp & $0.8061^{*}$ & 0.3575 & $0.6554^{*}$ & $-0.4363^{*}$ & 0.2843 & $0.8461^{*}$ \\
Maxtemp & 0.4198 & 0.3988 & 0.2427 & -0.0674 & 0.1641 & $0.7931^{*}$ \\
Abmin & $0.6347^{*}$ & 0.3915 & $0.8822^{*}$ & -0.1124 & -0.2813 & $0.7424^{*}$ \\
Abmax & -0.1151 & 0.3654 & -0.1451 & -0.0934 & 0.3208 & 0.0602 \\
Prec & -0.1865 & -0.3532 & -0.3234 & 0.2696 & $0.3806^{*}$ & -0.3965 \\
Neb & 0.3506 & -0.1834 & $0.4247^{*}$ & 0.0707 & -0.0846 & 0.1575 \\
RH & 0.3933 & $-0.7876^{*}$ & -0.0134 & 0.1692 & 0.0615 & 0.1304 \\
RD & 0.4348 & -0.2302 & 0.3391 & -0.0473 & 0.2563 & 0.1762 \\
\hline
\end{tabular}


matic limits. Therefore, the intersection between the areas delimited by climatic variables (climate envelope) and the vegetation map clipped to the Atlantic Forest ecoregions with occurrence points (vegetation envelope) resulted in a core area where each species should occur. The resulting potential distribution maps of Atlantic Forest Drymophila species are shown in figures 2-7.

\section{DISCUSSION}

All species studied occur only in the Atlantic Forest ecoregions. Therefore, the potential distribution hypotheses for these species are restricted to this biome, even though no climate envelopes were restricted to the Atlantic Forest boundaries.

A simple analysis overlaying the potential distribution map of each species with its climate and vegetational envelope maps indicated that either climate or vegetation, or a combination of both, are determinants of the potential geographic distribution of the Altantic Forest species of Drymophila. Among the six species analyzed, the distribution of three was delimited by climate alone; of two, by vegetation only; of one, by a combination of both factors.

Drymophila ferruginea and D. ochropyga had their potential distributions delimited only by vegetation, since the climate distribution of both species encompasses the totality of the Atlantic Forest. The potential geographical distribution maps of both species resulted in similar shapes.

Drymophila ferruginea occurs effectively in almost all of the Atlantic Forest up to the boundaries of two northeastern ecoregions (Pernambuco Coastal Forests and Pernambuco Interior Forests), which represent the northernmost limit of the species distribution, and the Atlantic Coast Restingas, which limits the species distribution in a very narrow southeastern coastal strip. Even though $D$. ferruginea could potentially occur in the Araucaria Moist forests, it is found only marginally in this region, which could be caused by the presence of its sister species $D$. rubricollis. In fact, $D$. ferruginea and $D$. rubricollis occur symparically only at middle elevations in a narrow strip of the southeastern mountains of Brazil (RAJÃo \& CERQUEIRA 2006).

The potential distribution of D. ochropyga, was determined by vegetation, with limits in the north (absence from Pernambuco Coastal Forests) and south (absence from Araucaria Moist Forests). Otherwise, the potential distributions of $D$. rubricollis, $D$. malura and D. squamata were determined by climate and not by vegetation.

Climate factors limit the potential distribution of $D$. rubricollis to the north, where this species could otherwise extend its distribution throughout the Bahia Coastal and Interior Forests. Likewise, the potential distribution of D. malura is limited to the north. Climate also limits the potential distribution of D. malura at Alto Paraná Atlantic Forest. Therefore, according the climate, D. malura can not be found at a Brazilian interior forest corridor, that extends northward through the state of Goiás. Climate limits the potential distribution of $D$. squamata in the south and southwest of the Atlantic Forest, preventing this species from extending its distribution throughout the Araucaria Moist Forest and Alto Paraná Atlantic Forest ecoregions.

A combination of climate and vegetation limit the potential distribution of only one species, D. genei. Climate is a limiting factor in the north and vegetation in the south, where D. genei is absent from the Araucaria Moist Forests. The sisterspecies $D$. ochropyga and D. genei occur in the same three ecoregions, being more frequent in the Serra do Mar Coastal Forests and Bahia Interior Forests. Neither species occur in the southern Araucaria Moist Forests, therefore differing from the other four species, or in the northern Pernambuco Coastal Forests. The potential distributions of these species differ mainly by the absence of D. genei from Bahia Coastal Forests and part of Bahia Interior Forests, where D. ochropyga occur.

The sister-species $D$. ferruginea and $D$. rubricollis are found in the same five ecoregions and are more frequent in the Serra do Mar Coastal Forests and Alto Paraná Atlantic Forests. The potential distribution of these two species differ mainly by the absence of $D$. rubricollis from part of the Bahia Coastal and Interior Forests ecoregions, where $D$. ferruginea occurs.

The potential distribution of $D$. squamata is certainly the most distinctive. Contrasting with the potential distributions of the other five species, it extends farthest north and occupies a more restricted area in the southern Araucaria Moist Forests and Alto Paraná Atlantic Forests ecoregions. Also, with $85 \%$ of localities in coastal ecoregions, both the potential and empirical distributions of D. squamata contrast with the other species of the genus, which are less represented in coastal regions.

The species that presented the highest percentages of correctly classified localities in the discriminant analysis were $D$. malura and D. squamata. These two species have distinct ecological requirements when compared with the other four species of Drymophila, all of which are more specialized in bamboo habitats than D. malura and D. squamata (LEME 2001, ZIMMER \& ISLER 2003).

The discrimination of Drymophila species based on climate data, as expected, was very low, considering that these birds can occur sympatrically. Compared to our analysis (general discrimination $38,8 \%$ ), the performance of a similar discriminant analysis (VILANOva et al. 2005), carried out on parapatric primate species of Cebus Erxleben, 1777, resulted in twice as many correct classifications (76.8\%). The percentage of correct cases classified, when each species was compared with the remaining group, were always higher for the Cebus analysis (between 76.4 and 87. 6\%) than for the species of Drymophila in our data (42.5 and $74.5 \%$ ). Both studies applied the same methods and climatic and vegetation variables to analyze potential distribution of Atlantic Forest endemic species groups. They differ, however in the biogeographic patterns of distribution of their subjects, parapatric in Cebus and 

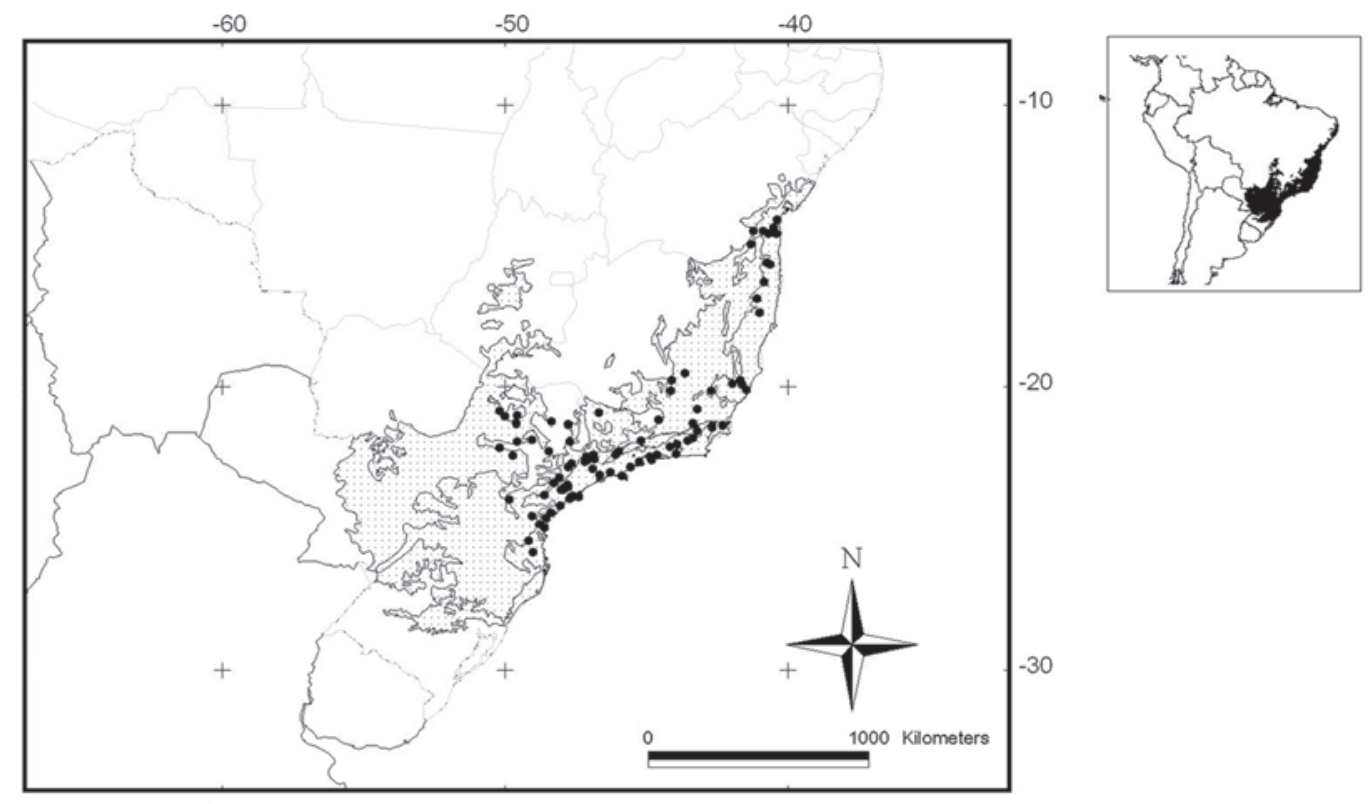

$-20$
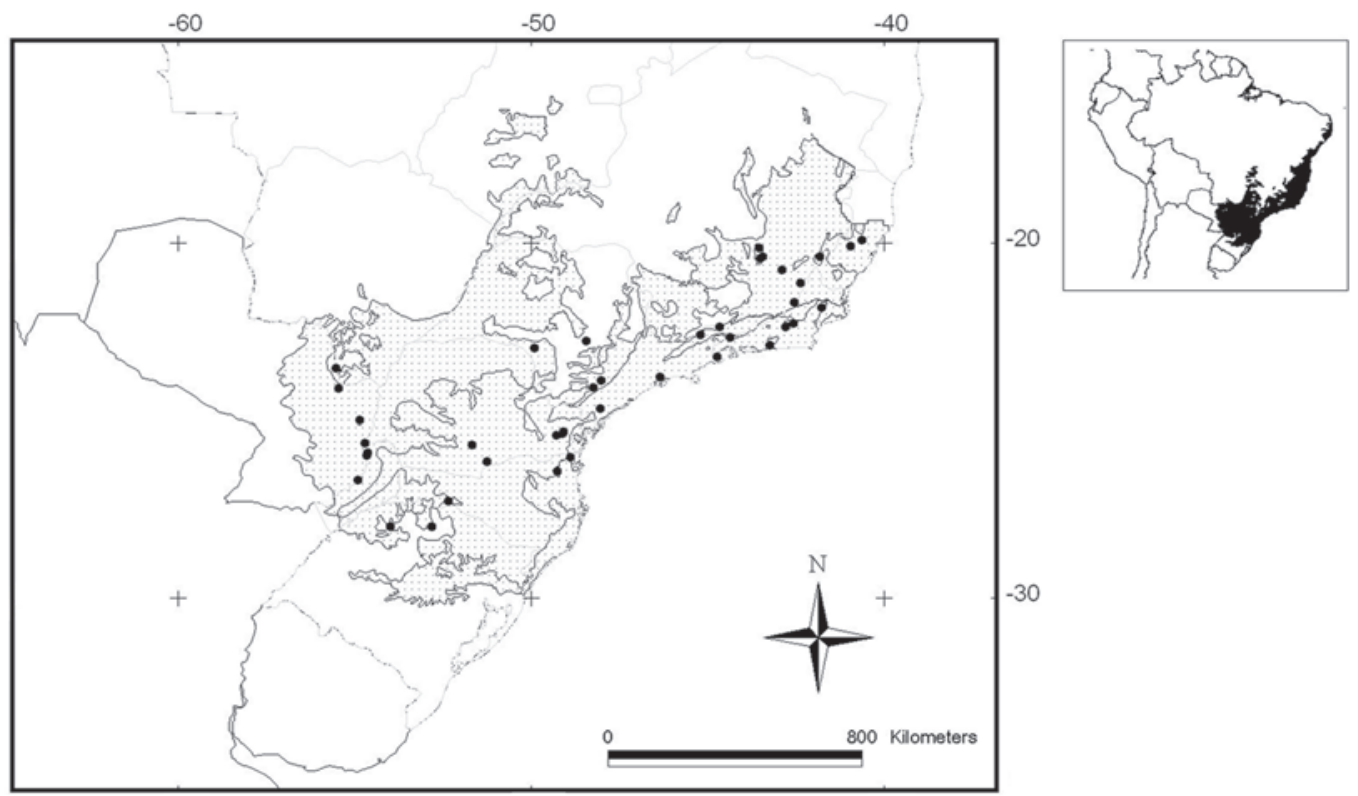

Figures 2-3. Potential distribution (shaded area) of Drymophila ferruginea (2) and D. rubricollis (3). Dots are recording localities.

sympatric in Drymophila. These results seem to corroborate the hypotheses that the discriminant approach is not appropriate to modeling potential distribution for sympatric species.

It is important to remark that, although this study has been able to compile the occurrence localities, to appoint po- tential distribution determinants and to model the potential geographic distribution of the Atlantic Forest Drymophila species, the discriminant approach applied here was not satisfactory. That was probably because at the biogeographic scale of the Atlantic Forest biome Drymophila can occur sympatrically in many localities and most species have highly superimposed 



$-20$
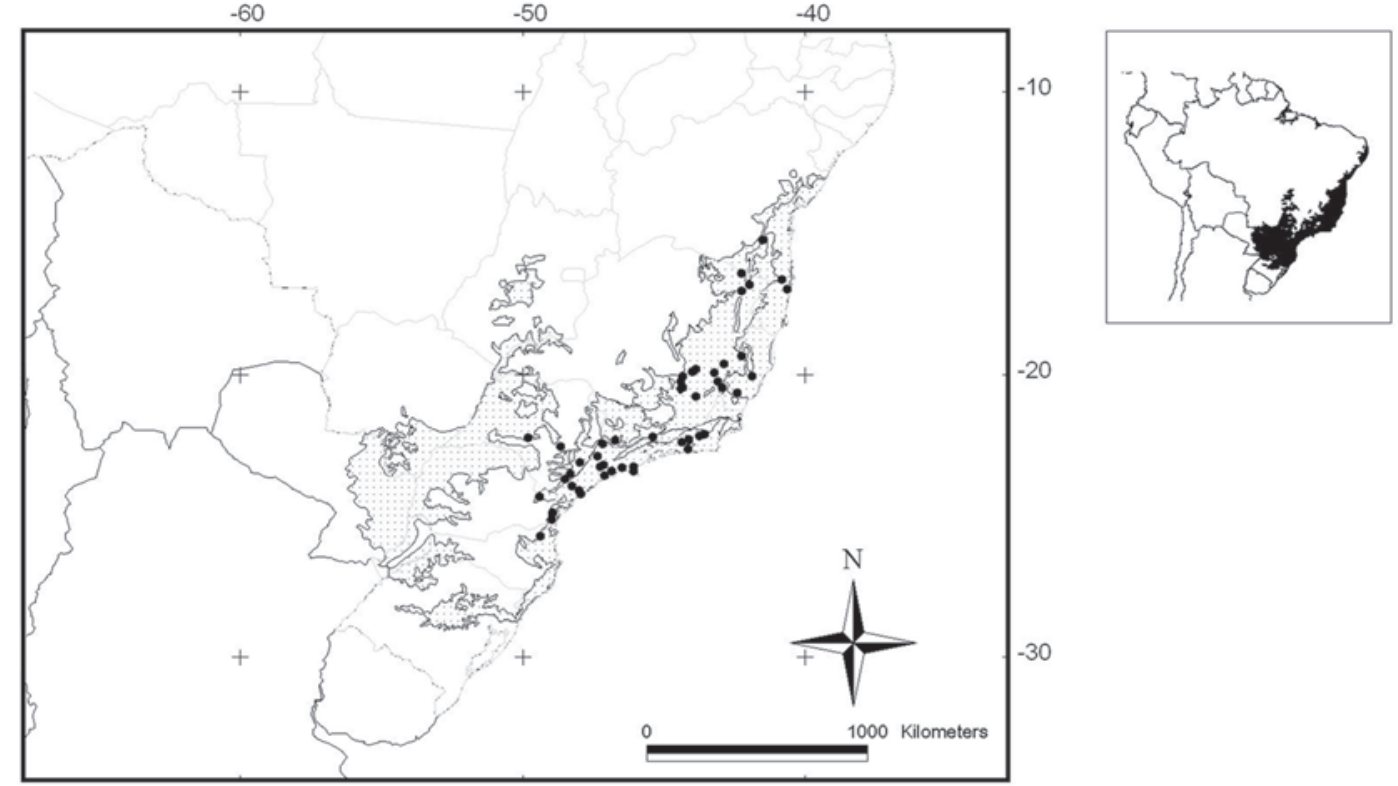

$-20$

$-30$

Figures 4-5. Potential distribution (shaded area) of Drymophila genei (4) and D. ochropyga (5). Dots are recording localities.

distributions. In turn, many localities present very similar climatic values, making the discrimination of the cases difficult. At the local scale Drymophila seems to exclude each other at regions of sympatry or co-ocurrence occupying sites with different characteristics of elevation, slope, aspect or fine vegetation type, as pointed by Rajão \& Cerqueira (2006). We suggest that future research addressing predictive geographical distribution modeling and coexistence of these antbirds species could be optimized by using a two part strategy: 1) by using novel machine-learning modeling algorithms; and (2) by improving the predictor variables database, both in thematic (e.g. including elevation and topographic variables) and spatial resolution 



$-20$


Figures 6-7. Potential distribution (shaded area) of Drymophila malura (6) and D. squamata (7). Dots are recording localities.

(e.g. using more fine-grained data).The use of novel machinelearning modeling algorithms have advantageous characteristics as for example the implementation of a generative rather than a discriminative approach, only requiring presence data and the capability to utilize both continuous and categorical data.

\section{ACKNOWLEDGMENTS}

We are grateful to Marcos Figueiredo for helpful suggestions on the manuscript and Paulo C. Cordeiro who kindly provided geographical data. We also thank CAPES and FAPERJ for post-graduate fellowships to HR, CAPES/PNPD for post-doctoral fellowship to MLL and CNPq for financial support. 


\section{LITERATURE CITED}

Austin, M. 2007. Species distribution models and ecological theory: A critical assessment and some possible new approaches. Ecological Modelling 200:1-19.

Boggs, C.L. \& D.D. Murphy. 1997. Community composition in mountain ecosystems: climatic determinants of montane butterfly distributions. Global Ecology and Biogeography Letters 6: 39-48.

IBGE. 1993. Mapa da vegetação brasileira. Rio de Janeiro, Ministério do Planejamento, Instituto Brasileiro de Geografia e Estatística.

Brown, J.H. \& M.V. Lomolino. 1998. Biogeography. Sunderland, Sinauer Associates, $2^{\text {nd }}$ ed., 691p.

Carrascal, L.M.; L.M. Bautista \& E. Lázaro. 1993. Geographical variation in the density of the white storck Ciconia ciconia in Spain: influence of habitat structure and climate. Biological Conservation 65: 83-87.

Catling, P.C.; R.J. Burt \& R.I. Forrester. 2000. Models of the distribution and abundance of ground-dwelling mammals in the eucalypt forests of north-eastern New South Wales in relation to habitat variables. Wildlife Research 27: 639-654.

Cerqueira, R. 1985. The distribution of Didelphis (Poliprotodontia, Didelphidae) in South America. Journal of Biogeography 12: $135-145$.

Cerqueira, R. 1995. Determinação de distribuições potenciais de espécies, p. 141-161. In: P. Peres-Neto; J.L. Valentin \& F.A.S. Fernandes (Eds). Oecologia Brasiliensis. Rio de Janeiro, Programa de Pós-Graduação em Ecologia, Instituto de Biologia, Universidade Federal do Rio de Janeiro, vol. 2, 161p.

Cerqueira, R.; G. Marroig \& L. Pinder. 1998. Marmosets and liontamarins distribution (Callitrichidae, Primates) in Rio de Janeiro state, south-eastern Brazil. Mammalia 62 (2): 213226.

Cordeiro, P.H.C. 2001. Areografia dos Passeriformes endêmicos da Mata Atlântica. Ararajuba 9 (2): 125-137.

Cueto, V.R. \& J.L. Casenave. 1999. Determinants of bird species richness: role of climate and vegetation structure at a regional scale. Journal of Biogeography 26: 487-492.

Dinerstein, E.; D.M. Olson; D.J. Graham; A.L. Webster; S.A. Primm; M.P. Bookbinder \& G. Ledec. 1995. A Conservation Assessment of the Terrestrial Ecoregions of Latin America and the Caribbean. Washington, DC, WWF, 192p.

EsRI. 2000. ArcView Gis 3.2a. Redlands, Environmental Systems Research Institute, Inc.

Fielding, A.H. \& J.F. Bell. 1997. . A review of methods for the assessment of prediction errors in conservation presence/ absence models. Environmental Conservation 24 (1): 38-49.

GoldEN. 2002. Surfer, Version 8.0. Colorado, Golden Software.

Grelle, C.E.V. \& R. Cerqueira. 2006. Determinantes da distribuição geográfica de Callithrix flaviceps (Thomas) (Primates, Callitrichidae). Revista Brasileira de Zoologia 23 (2): 311591.
Guisan, A. \& W. Thuiller. 2005. Predicting species distribution: offering more than simple habitat models. Ecology Letters 8: 993-1009.

Hijmans, R.J. \& C.H. Graham. 2006. The ability of climate envelope models to predict the effect of climate change on species distributions. Global Change Biology 12: 2272-2281.

JaCkson, S.M. \& A. Claridge. 1999. Climatic modeling of the distribution of the mahogany glider (Petaurus gracilis), and the squirrel glider ( $P$. norfolcensis). Australian Journal of Zoology 47: 47-57.

LAW, B.S. 1994. Climatic limitation of the southern distribution of the common blosson bat Syconycteris australis in New South Wales. Australian Journal of Ecology 19: 366-374.

LEME, A. 2001. Foraging patterns and resource use in four sympatric species of antwrens. Journal of Field Ornithology 72 (2): 221-227.

Lindenmayer, D.B.; H.A. Nix; J.P. Macmahon; M.F. Hutchinson \& T. TANTON. 1991. The conservation of leadbeater's possum, Gymnobelideus leadbeateri (McCoy): a case study of the use of bioclimatic modelling. Journal of Biogeography 18: 371383.

MacarthuR, R.H. 1972. Geographical ecology: patterns in the distributions of species. New York, Harper \& Row, 269p.

MACKey, B.G. \& D.B. LindenMAYER. 2001. Towards a hierarchical framework for modelling the spatial distribution of animals. Journal of Biogeography 28: 1147-1166.

Myers, A.A. \& P.S. Giller. 1988. Analytical Biogeography. London, Chapman and Hall, 578p.

NEWTON, I. 2003. The speciation and biogeography of birds. London, Academic Press, 668p.

Olson, D.M.; E. Dinerstein; E.D. Wikramanayake; N.D. Burgess; G.V.N. Powell; E.C. Underwood; J.A. D'Amico; I. Itoua; H.E. Strand; J.C. Morrison; C.J. LouCKS; T.F. AllnutT; T.H. RicketTs; Y. Kura; J.F. Lamoreux; W.W. Wettengel; P. Hedao \& K.R. Kassem. 2001. Terrestrial Ecoregions of the World: a new map of life on earth. BioScience 51: 933-938.

Pastor-Nieto, R. \& D.K. Willianson. 1998. The effect of rainfall seasonality on the geographic distribution of neotropical primates. Neotropical Primates 6 (1): 7-14.

Paynter, R.A. \& M.A. Traylor. 1991. Ornithological Gazeteer of Brazil. Massachusetts, Harvard University, 788p.

PinTo, O.M.O. 1978. Novo catálogo das aves do Brasil: primeira parte. São Paulo, Empresa Gráfica da Revista dos Tribunais, $446 p$.

Rajão, H. \& R. Cerqueira. 2006. Distribuição altitudinal e simpatria das aves do gênero Drymophila Swainson (Passeriformes, Thamnophilidae) na Mata Atlântica. Revista Brasileira de Zoologia 23 (3): 597-607.

Ridgely, R. \& G. Tudor. 1994. The birds of South America. Austin, University of Texas Press, vol. 2, 940p.

SICK, H. 1997. Ornitologia Brasileira. Rio de Janeiro, Editora Nova Fronteira, 912p.

Soberón, J. \& A.T. Peterson. 2005. Interpretation of models of 
fundamental ecological niches and species distributional areas. Biodiversity Informatics 2: 1-10.

SPSS. 1997. Systat 7.0 for Windows Software. Chicago, SPSS, Inc.

TAYLOR, R.A.J. \& L.R. TAYLOR. 1979. A behavioural model for the evolution of spatial dynamics, p. 1-28. In: R.M. ANDERSON; B.D. Turner \& L.R. Taylor (Eds). Population dynamics. Oxford, Blackwell Scientific Publications, 298p.

Terborgh, J. 1971. Distribution on environmental gradients: theory and a preliminary interpretation of distributional patterns in the avifauna of the Cordillera Vilcabamba, Peru. Ecology 52 (1): 23-40.

Terborgh, J. \& J.S. Weske. 1975. The role of competition in the distribution of Andean birds. Ecology 56 (3): 562-576.

United States Board On Geographical Names. Brazil. 1963. Official Standard Names. Washington, DC, Office of Geography, Department of Interior, 915p.

VAN VALEN, L. 1976. Ecological species, multispecies, and oaks. Taxon 25: 233-239.

Submitted: 04.II.2009; Accepted: 17.I.2010.

Editorial responsibility: Claudio J.B. de Carvalho
VAnZolini, P.E. 1992. A Supplement to the Ornithological Gazetteer of Brazil. São Paulo, Museu de Zoologia, Universidade de São Paulo, 252p.

Vilanova, R.; J.S. Silva Júnior; C.E.V. Grelle; G. Marroig \& R. Cerqueira. 2005. Limites climáticos e vegetacionais das distribuições de Cebus nigritus e Cebus robustus (Cebinae, Platyrrhini). Neotropical Primates 13 (1): 14-19.

WALker, P.A. 1990. Modelling wildlife distributions using a geographic information system: kangaroos in relation to climate. Journal of Biogeography 17: 279-289.

WhitTaker, R.H.; S.A. Levin \& R.B. Root. 1973. Niche, habitat, and ecotope. American Naturalist 107 (955): 321-338.

WILLIs, E.O. 1988. Drymophila rubricollis (Bertoni, 1901) is a valid species (Aves, Formicariidae). Revista Brasileira de Biologia 48 (3): 431-438.

ZimMER, K.J. \& M.L. IsLer. 2003. Family Thamnophilidae (Typical Antbirds), p. 448-681. In: J. Del Hoyo.; A. Elliott \& D. A. CHRISTIE (Eds). Handbook of the Birds of the World. Barcelona, Lynx Edicions, vol. 8, 845p. 